\title{
Przedsiębiorczość jako kompetencja kluczowa w systemie edukacji
}

DOI: $10.47050 / 65591760.16-34$

Tomasz Rachwał

Przedsiębiorczość jest pojęciem wieloznacznym i różnie definiowanym na gruncie poszczególnych dyscyplin naukowych, dla których stanowi ona przedmiot badań. W efekcie nie ma jednej, powszechnie akceptowanej definicji przedsiębiorczości. O ile w dyskursie naukowym taki stan rzeczy należy traktować jako normalny, to wydaje się, że na potrzeby edukacyjne konieczne jest przyjęcie jednej wspólnej definicji. Umożliwia to bowiem budowanie skutecznych strategii edukacyjnych, formułowania podstaw programowych i programów nauczania, w ramach których będziemy zgodni jakie konkretnie kompetencje przedsiębiorcze uczniów chcemy kształtować. Jedną z takich możliwości jest przyjęcie europejskiej koncepcji przedsiębiorczości jako kompetencji kluczowej. W rozdziale na tle literatury przedmiotu przedstawiono zmiany w zakresie deskrypcji przedsiębiorczości jako jednej z ośmiu kompetencji kluczowych w europejskim systemie edukacji.

\section{Słowa kluczowe:}

edukacja w zakresie przedsiębiorczości

kompetencje kluczowe

kompetencje w zakresie przedsiębiorczości

przedsiębiorczość

system edukacji 


\section{Entrepreneurship as a key competence in education system}

DOI: 10.47050/65591760.16-34

Tomasz Rachwał

Entrepreneurship is an ambiguous concept, variously defined on the basis of individual scientific disciplines for which it is the subject of research. As a result, there is no single widely accepted definition of entrepreneurship. While in the scientific discourse this status should be treated as normal, it seems that for educational purposes it is necessary to adopt one common definition. This allows for building effective educational strategies, formulating core and school curricula, within which we will agree on what specific entrepreneurial competences of pupils we want to develop. One of these possibilities is the adoption of the European concept of entrepreneurship as key competence. On the background of the literature on the subject this chapter refers to the presents changes in the scope of the description of entrepreneurship as one of the eight key competences in the European education system.

\section{Keywords:}

entrepreneurship education

entrepreneurship competences

entrepreneurship

education system

key competences 


\section{Wstęp}

Przedsiębiorczość jest w ostatnich latach niezmiernie popularnym pojęciem w dyskursie zarówno społecznym jak i naukowym. Można nawet powiedzieć, że stała się niezwykle modna. Pojawia więc coraz więcej różnego typu "przedsiębiorczych" projektów czy strategii i programów mających na celu jej rozwój. Wynika to z faktu, że powszechnie uznaje się jej dużą rolę w życiu człowieka, społeczeństwa, funkcjonowaniu gospodarki i jej podmiotów, w szczególności przedsiębiorstw i rożnego typu instytucji. Przymiotnik "przedsiębiorczy" odnosi się już nie tylko człowieka, ale też do organizacji, w tym przedsiębiorstw i uniwersytetów (Wach 2014a, Zioło 2016), a także układów przestrzennych - regionów (Godlewska-Majkowska 2015, Pilewicz 2012, Płaziak, Rachwał 2015) czy miast (Szromnik 2012), a nawet całej gospodarki (Wach 2014b). Powoduje to, że w literaturze przedmiotu pojawia się wiele jej definicji, w zależności od celów i przedmiotu rozważań podejmowanych przez różnych autorów. Konieczne jest jednak przyjęcie dla celów edukacyjnych w miarę spójnego, jednego spojrzenia na przedsiębiorczość. W przeciwnym razie niezmiernie trudno będzie konstruować skuteczne strategie i programy edukacji w zakresie przedsiębiorczości lub będą one realizować zbyt różne, odległe od istoty przedsiębiorczości cele, czasem nawet sprzeczne ze sobą. Dlatego też głównym celem niniejszego tekstu jest wykazanie możliwości przyjęcie na potrzeby edukacyjne europejskiej definicji przedsiębiorczości jako kompetencji kluczowej, analiza zmian jej szczegółowej deskrypcji w ostatnich latach na tle dyskusji w literaturze przedmiotu odnoszącej się do miejsca przedsiębiorczości w systemie kompetencji.

\section{Pojmowanie przedsiębiorczości na gruncie różnych nauk a potrzeby edukacyjne}

Powszechnie przyjmuje się, że przedsiębiorczość jest pojęciem polisemicznym, ale też nie zawsze właściwie rozumianym, w wyniku traktowania jej zbyt wąsko lub zbyt szeroko, a czasem nawet wkładania weń sprzecznych treści (Brzozowski 2007). Niewątpliwie jest ona zjawiskiem bardzo złożonym i wielowymiarowym, o czym zdaniem J. Cieślika (2014, s.19), „świadczy fakt, że mimo prowadzonych od XVIII w. badań, w gronie naukowców zajmujących się tą problematyką występuje nadal wiele kontrowersji i wątpliwości, dotyczących fundamentalnych kwestii - począwszy od definicji przedsiębiorcy oraz interpretacji przedsiębiorczości 
jako zjawiska społeczno-gospodarczego". Nie ma także nawet zgody co do umiejscowienia przedsiębiorczości jako subdyscypliny naukowej, przypisywanej zarówno do nauk w zakresie zarządzania, ekonomii, geografii społeczno-ekonomicznej, jak i socjologii, psychologii, historii i innych dyscyplin, dla których również stanowi przedmiot badań (Cieślik 2014, 2015, Rachwał 2018, Wach 2014c, 2015). Odmienność spojrzeń przedstawicieli różnych dyscyplin na przedsiębiorczość wpływa na różne jej ujęcia i różne podejścia badawcze. Przykładowo w naukach o zarządzaniu duże znaczenie ma ujęcie przedsiębiorczości jako procesu (Gaweł 2013, Glinka, Gudkova 2013), w publikacjach ekonomicznych problematyka przedsiębiorczości często koncentrowana jest na kwestii samozatrudnienia czy sektora małych i średnich przedsiębiorstw (Wach 2015). W dodatku w warunkach polskich należy uwzględnić wciąż istniejącą dotkliwą luką badawczą $w$ dziedzinie przedsiębiorczości powstałą w naszym kraju w ciągu dziesięcioleci gospodarki socjalistycznej (Kraśnicka 2011). W geografii społeczno-ekonomicznej kładzie się z kolei nacisk na przestrzenne aspekty rozwoju przedsiębiorczości i jej rolę w aktywizacji gospodarczej i rozwoju układów przestrzennych różnej skali, od lokalnej, przez ponadlokalną i regionalną po skalę krajową (Rachwał 2018, Zioło, Rachwał 2012). Należy się więc zgodzić z K. Wachem (2015), że przedsiębiorczość jako obszar badawczy cechuje wyjątkowa multidyscyplinarność, co oznacza, że badania prowadzone w wielu dyscyplinach naukowych odrębnie i interdyscyplinarność (badania na styku co najmniej dwóch dyscyplin naukowych). Dynamiczny rozwój badań nad przedsiębiorczością i szeroka dyskusja w obrębie oraz na styku wielu dyscyplin naukowych powoduje, że to fundamentalne pojęcie definiowane jest $w$ niejednolity sposób i nie ma powszechnej zgody na jedną definicję przedsiębiorczości. Nie zmienia to jednak faktu, że konieczne jest jej zdefiniowanie na potrzeby edukacji. Jeśli jesteśmy zgodni, że przedsiębiorczość zajmuje lub powinna zajmować znaczące w niej miejsce, to nie można zadowolić się stwierdzeniami, że jest to pojęcie wieloznaczne, a każdy z autorów przyjmuje własną definicję. Nie jest też możliwe bezpośrednie przeniesienie definicji z jednej z nauk, zresztą nawet w poszczególnych dyscyplinach naukowych trudno mówić nawet o powszechności jednej z definicji, a tym bardziej pełnej dla niej akceptacji. Jednak budowanie skutecznej strategii kształtowania kompetencji przedsiębiorczych w systemie edukacji od najmłodszych lat wymaga przyjęcia takiego w miarę jednolitego ujęcia 
przedsiębiorczości.Należy mieć bowiem na uwadze, że odbiorcą tej definicji, są nie tyle badacze, ale przede wszystkim decydenci w obszarze edukacji, autorzy podstaw programowych, programów nauczania i podręczników oraz nauczyciele i wreszcie - sami uczniowie. Ważne jest tu przyjęcie pewnej bazy pojęciowej do podejmowanych działań edukacyjnych w tym zakresie, szczególnie w ramach edukacji formalnej, ale także pozaformalnej i nieformalnej, tak istotnych w erze dynamicznych przemian społeczno-gospodarczych i turbulencji otoczenia.

\section{Przedsiębiorczość jako kompetencja}

Jeszcze stosunkowo niedawno pojęcie kompetencji było definiowane jako nadany, na podstawie faktycznych kwalifikacji, zakres pełnomocnictw i uprawnień. Takie ujęcie powodujące swoistą nadrzędność kompetencji nad kwalifikacjami wciąż obowiązuje w niektórych profesjach (Kwiatkowski 2018). Tego typu podejścia definicyjne spotykane są nadal w opracowaniach branżowych i słownikach językowych (np. "Słownik języka polskiego", 2005). Współcześnie przyjmuje się jednak szersze ujęcie tego pojęcia, szczególnie w odniesieniu do efektów uczenia się $\mathrm{w}$ różnych formach edukacji. W ich skład wchodzą (Kwiatkowski 2018):

$\rightarrow$ wiedza, a więc zbiór faktów, praw, teorii, zasad i doświadczeń przyswojonych lub samodzielnie skonstruowanych,

$\rightarrow$ umiejętności, a więc zdolność/gotowość do wykorzystania wiedzy podczas realizacji różnego rodzaju zadań,

$\rightarrow$ kompetencje społeczne, w więc zdolność do projektowania i kształtowania własnego rozwoju oraz autonomicznego i odpowiedzialnego udziału w życiu społeczno-zawodowym.

Takie podejście do kompetencji jest powszechnie stosowane w systemach edukacji, zostało między innymi wprowadzone do systemu szkolnictwa w ramach Krajowych Ram Kwalifikacji (obecnie Polskich Ram Kwalifikacji), co znajduje swoje powszechne odzwierciedlenie w zapisach programów studiów, gdzie określa się efekty kształcenia w zakresie wiedzy, umiejętności i kompetencji społecznych. Takie ujęcie kompetencji jest często przyjmowane także na niższych poziomach edukacji, co znalazło również swoje odzwierciedlenie w zapisach podstawy programowej dla szkół podstawowych i średnich z zakresu geografii i podstaw przedsiębiorczości (Rachwał i in. 2018, Szkurłat 
i in. 2018, zob. także kolejny rozdział autorstwa W. Kilar i T. Rachwała). Czasem do tego zestawu trzech podstawowych elementów dodaje się także cechy osobowości.

Warto zwrócić uwagę, za D. Piróg (2015), że termin kompetencja ma wiele znaczeń i choć pojawił się w literaturze naukowej stosunkowo niedawno, stał się przedmiotem badań wielu specjalistów, m.in. z zakresu pedagogiki pracy, polityki społecznej, ekonomii, socjologii, psychologii oraz dydaktyki szkoły wyższej. Zdaniem autorki wielodziedzinowy charakter pojęcia kompetencja skutkuje mnogością spojrzeń na nie i w konsekwencji powstaniem wielu definicji. Różnorodność ta jest również związana ze współwystępowaniem dwóch sposobów rozumienia kompetencji, które w języku angielskim są odzwierciedlone za pomocą słów competency i competence. Autorka wskazuje, że pierwszy termin wywodzi się ze Stanów Zjednoczonych, gdzie kompetencje mają podłoże behawioralne i są ujmowane jako sposób zachowania, który wpływa na powodzenie wykonywanych zadań. W tym rozumieniu kompetencje zbudowane są zazwyczaj ze składowych wiedzy, umiejętności i przejawianych postaw, które to postawy są uzewnętrznioną, wyuczoną - w różnych środowiskach skłonnością człowieka do określonych zachowań i działań. Natomiast inne rozumienie terminu kompetencje mieści się pod wyrazem competence. Termin ten, powstały na gruncie brytyjskim, skupia się na wystandaryzowanych wynikach wykonywanych działań, przypisanych np. do zawodu czy stanowiska pracy (Piróg 2015). To pierwsze podejście zatem odpowiada bardziej temu, co zostało przyjęte w systemie edukacji w ramach kształcenia ogólnego, to drugie bardziej nawiązuje do celów kształcenia zawodowego.

Generalnie ujmując kompetencje można więc podzielić na ogólne i zawodowe. Te pierwsze zalicza się do podstawowych efektów uczenia się w ramach kształcenia ogólnego, które realizowane jest głównie w szkołach podstawowych, liceach ogólnokształcących i częściowo w szkolnictwie zawodowym, gdzie jednak ze zrozumiałych względów większą wagę przywiązuje się do kompetencji zawodowych (Kwiatkowski 2018). Kompetencje ogólne z punktu widzenia edukacyjnego wiążą się przede wszystkim z rozwojem intelektualnym uczniów, a zawodowe są kształtowane w celach związanych z przyszłą pracą. Choć w praktyce gospodarczej kompetencje zawodowe uzyskane podczas formalnej edukacji przyjmują postać kwalifikacji zawodowych i posiadają 
określoną wartość rynkową, w odróżnieniu od większości kompetencji ogólnych, to jednak kompetencje ogólne należy traktować jako fundament kompetencji zawodowych (Kwiatkowski 2018). Wśród kompetencji ogólnych mieści się przedsiębiorczość, która wskazywana jest jako jedna z podstawowych kompetencji z punktu widzenia tranzycji i funkcjonowania jednostki na rynku pracy, podejmowania samozatrudnienia, podnoszenia konkurencyjności przedsiębiorstw oraz procesów rozwoju gospodarczego (Białasiewicz 2008, Korpysa 2013, Kwiatkowski 2018, Piróg 2013, 2014, 2015, 2016, Wach 2013, Zioło 2012, Zioło, Rachwał 2012). Stąd M. Tracz (2006) wskazuje na dużą rolę jej kształtowania w kształceniu ogólnym. Ze względu na rosnące jej znaczenie w obecnej fazie rozwoju cywilizacyjnego jest ona określana także jako kompetencja przyszłości (Borowiec, Kilar, Rachwał 2018).

Powszechnie przyjmuje się, że na przedsiębiorczość jako kompetencję składa się wiele elementów. Wcześniej w literaturze polskiej były one określane jako cechy postawy przedsiębiorczej (Borowiec, Rachwał 2011, Piróg 2015, Rachwał 2005, 2006, Strojny 2007). Stąd należy raczej mówić o kompetencjach przedsiębiorczych czy kompetencjach w zakresie przedsiębiorczości, zatem w liczbie mnogiej. D. Piróg (2015) w wyniku obszernego studium zagranicznej literatury przedmiotu zwróciła uwagę na ewolucję konceptualizacji kompetencji z zakresu przedsiębiorczości oraz zestawu kompetencji, które charakteryzują osobę przedsiębiorczą. W wyniku tego przeglądu autorka uznała, że kompleksową, najnowszą propozycją w tym zakresie jest opracowanie autorstwa S. Mitchelmore i J. Rowley (2010). W wyniku głębokiej analizy literatury zestawiły one 25 kompetencji, które inni specjaliści podejmujący tę problematykę najczęściej uwzględniali w swoich badaniach i podzieliły je na kompetencje osobowościowe (społeczne), behawioralne (osobiste) oraz menadżerskie (Piróg 2015)1.

Inny zestaw kompetencji przedsiębiorczych na potrzeby systemu edukacji opracowano w ramach dużego projektu europejskiego wykonanego na zlecenie Komisji Europejskiej EntreComp: The Entrepreneurship Competence Framework. W efekcie jego realizacji opracowano ramy (tj. model koncepcyjny i szczegółową definicję) kom-

1. Klasyfikację i szczegółowy wykaz kompetencji z zakresu przedsiębiorczości na podstawie artykułu S.Mitchelmore i J. Rowley (2010) przedstawiła w swojej pracy D. Piróg (2015, tab. 2, s. 371). 
petencji przedsiębiorczych (Bacigalupo i in. 2016). Ramy te określają przedsiębiorczość jako kompetencję przekrojową, która dotyczy ludzi we wszystkich sferach życia, od rozwoju osobistego przez aktywne uczestnictwo w społeczeństwie, do wejścia/ponownego wejścia na rynek pracy jako pracownik lub osoba samozatrudniona, a także do rozpoczynania różnego typu przedsięwzięć (kulturalnych, społecznych lub gospodarczych). Według wypracowanej koncepcji dzieli się je na trzy kategorie obejmujące: idee i możliwości ich realizacji, zasoby oraz działanie (Bacigalupo i in. 2016, Carlebach 2016, Kwiatkowski 2018). Kompetencje przynależne poszczególnym obszarom są następujące (Bacigalupo i in. 2016):

1) kategoria „idee i możliwości” (ang. ideas and opportunities)

$\rightarrow$ dostrzeganie możliwości,

$\rightarrow$ kreatywność,

$\rightarrow$ tworzenie wizji,

$\rightarrow$ ocena idei (pomysłów),

$\rightarrow$ etyka i "zrównoważone" myślenie (ang. sustainable thinking),

2) kategoria "zasoby" (ang. resources)

$\rightarrow$ samoświadomość i poczucie własnej skuteczności

$\rightarrow$ motywacja i wytrwałość,

$\rightarrow$ mobilizowanie zasobów (pozyskanie i zarządzanie zasobami),

$\rightarrow$ kompetencje związane $z$ wiedzą finansową i ekonomiczną,

$\rightarrow$ mobilizowanie innych.

3) kategoria "działanie" (ang. taking into action)

$\rightarrow$ przejmowanie inicjatywy,

$\rightarrow$ planowanie i zarządzanie,

$\rightarrow$ radzenie sobie z niejednoznacznością, niepewnością i ryzykiem,

$\rightarrow$ umiejętność pracy z innymi (współpracy w zespole),

$\rightarrow$ ciągłe uczenie się poprzez doświadczenie.

Ramy te są ciekawą próbą porządkowania, grupowania i konkretyzowania kompetencji w zakresie przedsiębiorczości i nawiązują do europejskiej definicji przedsiębiorczości jako kompetencji kluczowej.

\section{Europejska koncepcja przedsiębiorczości} jako kompetencji kluczowej

W wyniku wieloletnich prac zespołu roboczego w ramach Komisji Europejskiej przedsiębiorczość uznano za jedną z ośmiu kompetencji klu- 
czowych w procesie uczenia się przez całe życie. Kompetencje kluczowe stanowią połączenie wiedzy, umiejętności i postaw, które wszystkie osoby potrzebują dla samorealizacji i rozwoju osobistego, bycia aktywnym obywatelem, integracji społecznej oraz zatrudnienia (Zalecenie... 2006). Choć z oczywistych względów traktatowych, z których jednoznacznie wynika, że każdy kraj członkowski ma prawo wg swojego uznania kształtować swój system edukacji, jest to tylko "miękki" dokument wspólnotowy, ogłoszony w formie zalecenia Parlamentu Europejskiego i Rady UE, to jednak koncepcja ta jest sukcesywnie wdrażana w krajach Unii Europejskiej. Została ona rozpropagowana w postaci szeregu raportów, dokumentów roboczych i materiałów promocyjnych (m.in. Eurydice, np. Kompetencje kluczowe 2007), dzięki czemu przyjmowana jest ona także, przynajmniej częściowo, nie tylko w krajach członkowskich, ale także innych krajach europejskich, szczególnie Europejskiego Obszaru Gospodarczego, a nawet w krajach pozaeuropejskich.

W wyniku okresowego przeglądu kompetencji po ponad 10 latach wdrażania koncepcji dokonano, zgodnie z założeniami nowego europejskiego programu na rzecz umiejętności, pewnych korekt, wynikających z procesów rozwoju cywilizacyjnego i diagnozy stanu i potrzeb edukacyjnych (Tab. 1). Jak wskazano w nowym Zaleceniu Rady UE (2018, s. 1, par. 4) „obecnie wymagania dotyczące kompetencji uległy zmianie w związku z rosnącą liczbą miejsc pracy poddanych automatyzacji, coraz istotniejszą rolą technologii we wszystkich dziedzinach pracy i życia oraz zwiększającym się znaczeniem kompetencji społecznych, obywatelskich i w zakresie przedsiębiorczości, które pozwalają zapewnić odporność i zdolność dostosowania się do zmian". Jednocześnie zwrócono uwagę, że badania prowadzone w Europie wskazują na utrzymujący się wysoki odsetek nastolatków i dorosłych mających niewystarczające umiejętności podstawowe. W 2015 r. co piąty uczeń miał poważne trudności w osiągnięciu wystarczającego poziomu umiejętności w zakresie czytania ze zrozumieniem, myślenia matematycznego lub rozumienia zjawisk przyrodniczych. W niektórych krajach nawet co trzeci dorosły ma umiejętność rozumienia i tworzenia informacji oraz rozumowania matematycznego jedynie na najniższym poziomie. 44 proc. ludności Unii ma niskie umiejętności cyfrowe, a 19 proc. nie ma ich wcale (Zalecenie... 2018). 
Tabela 1. Kompetencje kluczowe w europejskim systemie edukacji

\begin{tabular}{|c|c|}
\hline $\begin{array}{l}\text { KOMPETENCJE WG "STAREGO" UKŁADU } \\
\text { (ZALECENIE... 2006) }\end{array}$ & $\begin{array}{l}\text { KOMPETENCJE WG „NOWEGO" UKŁADU } \\
\text { (ZALECENIE... 2018) }\end{array}$ \\
\hline 1) porozumiewanie się w języku ojczystym; & \multirow{2}{*}{$\begin{array}{l}\text { 1) kompetencje w zakresie rozumienia i tworze- } \\
\text { nia informacji, } \\
\text { 2) kompetencje w zakresie wielojęzyczności, }\end{array}$} \\
\hline 2) porozumiewanie się w językach obcych; & \\
\hline $\begin{array}{l}\text { 3) kompetencje matematyczne i podsta- } \\
\text { wowe kompetencje naukowo-technicz- } \\
\text { ne; }\end{array}$ & $\begin{array}{l}\text { 3) kompetencje matematyczne oraz kompetencje } \\
\text { w zakresie nauk przyrodniczych, technologii } \\
\text { i inżynierii, }\end{array}$ \\
\hline 4) kompetencje informatyczne; & 4) kompetencje cyfrowe, \\
\hline 5) umiejętność uczenia się; & \multirow{2}{*}{$\begin{array}{l}\text { 5) kompetencje osobiste, społeczne i w zakresie } \\
\text { umiejętności uczenia się, } \\
\text { 6) kompetencje obywatelskie, }\end{array}$} \\
\hline 6) kompetencje społeczne i obywatelskie; & \\
\hline 7) inicjatywność i przedsiębiorczość; & 7) kompetencje w zakresie przedsiębiorczości, \\
\hline 8) świadomość i ekspresja kulturalna & $\begin{array}{l}\text { 8) kompetencje w zakresie świadomości i ekspresji } \\
\text { kulturalnej. }\end{array}$ \\
\hline
\end{tabular}

Źródło: Opracowanie własne na podstawie Zalecenie... (2006) i Zalecenie... (2018).

Jak widać zmiany w zakresie kompetencji w niektórych aspektach są znaczące. Między innymi zrezygnowano z podziału kompetencji językowych na język ojczysty i obcy, zastępujące je kompetencjami w zakresie rozumienia i tworzenia informacji oraz wielojęzyczności. Zmiany takie nie nastąpiły w odniesieniu do przedsiębiorczości, która - jak podkreślono w nowym Zaleceniu (2018) jest jedną z kompetencji, których znaczenie rośnie. Uproszczono słusznie nazwę tej kompetencji, gdyż była nieco myląca. Powszechnie przecież wskazuje się inicjatywność jako cechę (Rachwał 2005, 2006, Borowiec, Rachwał 2011, Borowiec, Kilar, Rachwał 2018) lub składową kompetencji behawioralnych (osobistych) osoby przedsiębiorczej (Piróg 2015). Poprzednia nazwa tej grupy kompetencji, gdzie inicjatywność była współrzędnie połączona z przedsiębiorczością spójnikiem „" oraz w dodatku występowała na pierwszym miejscu, była więc niezbyt fortunna.

Jeśli chodzi o zmianę samej definicji kompetencji w zakresie przedsiębiorczości, to nie jest ona znacząca w sensie merytorycznym, w porównaniu z głębokimi zmianami w przypadku niektórych innych kompetencji (Tab. 2). Choć nowe ujęcie jest nieco krótsze, to jego sens został zachowany. Zwrócono jednak bardziej uwagę na czym się opierają niż czemu służą. Choć nowe brzmienie wydaje się bardziej konkretne 
i precyzyjne, to za nienajlepsze rozwiązanie należy uznać wyeliminowanie aspektu etycznego podejmowanych działań. Zostało to w zamian mocniej wyakcentowane w dalszej części opisu tej kompetencji.

Tabela 2. Zmiana europejskiej definicji kompetencji

w zakresie przedsiębiorczości

\begin{tabular}{l|l}
\multicolumn{1}{c|}{$\begin{array}{c}\text { INICJATYWNOŚĆ I PRZEDSIĘBIORCZość } \\
\text { (ZALECENIE... 2006) }\end{array}$} & \multicolumn{1}{c}{$\begin{array}{c}\text { KOMPETENCJE W ZAKRESIE } \\
\text { PRZEDSIĘBIORCZOŚCI (ZALECENIE... 2018) }\end{array}$} \\
\hline $\begin{array}{l}\text { Inicjatywność i przedsiębiorczość oznaczają zdolność } \\
\text { osoby do wcielania pomysłów w czyn. Obejmują one } \\
\text { kreatywność, innowacyjność i podejmowanie ryzyka, }\end{array}$ & $\begin{array}{l}\text { Kompetencje w zakresie przedsię- } \\
\text { biorczości to między innymi zdolność }\end{array}$ \\
a także zdolność do planowania przedsięwzięć i prowa- & wykorzystywania szans i pomysłów \\
dzenia ich dla osiągnięcia zamierzonych celów. Stanowią & oraz przekształcania ich w wartość dla \\
one wsparcie dla indywidualnych osób nie tylko w ich & ingób. Przedsiębiorczość opiera \\
codziennym życiu prywatnym i społecznym, ale także & myśleniu i rozwiązywaniu problemów, \\
w ich miejscu pracy pomagając im uzyskać świadomość & podejmowaniu inicjatywy, wytrwałości \\
kontekstu ich pracy i zdolność wykorzystywania szans; & oraz na zdolności do wspólnego dzia- \\
są podstawą bardziej konkretnych umiejętności i wiedzy & łania służącego planowaniu projektów \\
potrzebnych tym, którzy podejmują przedsięwzięcia & mających wartość kulturalną, społecz- \\
o charakterze społecznym lub handlowym lub w nich & ną lub finansową i zarządzaniu nimi. \\
uczestniczą. Powinny one obejmować świadomość war- & \\
tości etycznych i promować dobre zarządzanie. &
\end{tabular}

Źródło: opracowanie własne na podstawie Zalecenie... (2006) i Zalecenie... (2018).

Druga część definicji kompetencji kluczowych jest charakterystyką niezbędnej wiedzy, umiejętności i postaw powiązane z daną kompetencją. Nowa deskrypcja jest nieco bardziej obszerna od poprzedniej (Tab. 3). Pojawiają się w niej nowe odniesienia do proaktywności (współcześnie niezmiernie ważnej), zdolności do empatii, troski o innych ludzi i świat, a także przyjmowania odpowiedzialności i postaw etycznych. Mocniej wyakcentowano także kwestie rozumienia procesów ekonomicznych, zdolności podejmowania decyzji finansowych, skutecznego komunikowania się i negocjowania z innymi osobami, a także radzenia sobie z niepewnością, dwuznacznością i ryzykiem jako elementami procesu podejmowania świadomych decyzji. 


\section{Tabela 3. Zmiana w zakresie wiedzy, umiejętności i postaw związanych z definicją kompetencji w zakresie przedsiębiorczości}

INICJATYWNOŚĆ I PRZEDSIĘBIORCZOŚĆ

(ZALECENIE... 2006)

Niezbędna wiedza, umiejętności i posta-

wy powiązane z tą kompetencją:

Konieczna wiedza obejmuje zdolność identyfikowania dostępnych możliwości działalności osobistej, zawodowej lub gospodarczej, w tym szerszych zagadnień stanowiących kontekst pracy i życia ludzi, takich jak ogólne rozumienie zasad działania gospodarki, a także szanse i wyzwania stojące przed pracodawcami i organizacjami. Osoby powinny również być świadome zagadnień etycznych związanych z przedsiębiorstwami oraz tego, w jaki sposób mogą one wywoływać pozytywne zmiany, np. poprzez sprawiedliwy handel lub przedsięwzięcia społeczne.

Umiejętności odnoszą się do proaktywnego zarządzania projektami (co obejmuje np. planowanie, organizowanie, zarządzanie, kierowanie i zlecanie zadań, analizowanie, komunikowanie, sporządzanie raportów, ocenę i sprawozdawczość), skutecznej reprezentacji i negocjacji oraz zdolności zarówno pracy indywidualnej, jak i współpracy w zespołach. Niezbędna jest umiejętność oceny i identyfikacji własnych mocnych i słabych stron, a także oceny ryzyka i podejmowania go w uzasadnionych przypadkach.

Postawa przedsiębiorcza charakteryzuje się inicjatywnością, aktywnością, niezależnością i innowacyjnością zarówno w życiu osobistym i społecznym, jak i w pracy. Obejmuje również motywację i determinację w kierunku realizowania celów, czy to osobistych, czy wspólnych, zarówno prywatnych jak i w pracy
KOMPETENCJE W ZAKRESIE PRZEDSIĘBIORCZOŚCI (ZALECENIE... 2018)

Niezbędna wiedza, umiejętności i postawy powiązane z tą kompetencją:

Kompetencje w zakresie przedsiębiorczości wymagają świadomości istnienia różnych kontekstów i różnych możliwości pozwalających przekształcać pomysły w działanie w sferze osobistej, społecznej i zawodowej, a także rozumienia procesu ich powstawania. Niezbędna jest znajomość i rozumienie podejść do planowania i zarządzania projektami, obejmujących zarówno procesy, jak i zasoby. Konieczne jest rozumienie procesów ekonomicznych oraz szans i wyzwań społecznych i gospodarczych stojących przed pracodawcą, organizacją lub społeczeństwem. Niezbędna jest również świadomość zasad etycznych, wyzwań w zakresie zrównoważonego rozwoju, a także własnych atutów i słabości.

Umiejętności w zakresie przedsiębiorczości opierają się na kreatywności - obejmującej wyobraźnię, myślenie strategiczne i rozwiązywanie problemów - oraz na krytycznej i konstruktywnej refleksji w ramach ewoluujących procesów twórczych i na innowacji. Obejmują one zdolność pracy samodzielnej i zespołowej, mobilizowania zasobów (ludzi i przedmiotów) oraz prowadzenia działalności gospodarczej. Uwzględnia to również zdolność podejmowania decyzji finansowych związanych z kosztem i wartością. Kluczowe znaczenie ma zdolność skutecznego komunikowania się i negocjowania z innymi osobami, a także radzenia sobie z niepewnością, dwuznacznością i ryzykiem jako elementami procesu podejmowania świadomych decyzji.

Postawa przedsiębiorcza charakteryzuje się zmysłem inicjatywy i poczuciem sprawczości, proaktywnością, otwartością na przyszłość, odwagą i wytrwałością w dążeniu do celów. Obejmuje pragnienie motywowania innych osób i doceniania ich pomysłów, odczuwanie empatii i troskę o innych ludzi i świat, a także przyjmowanie odpowiedzialności i postaw etycznych w całym procesie. 
Warto podkreślić, że wszystkie kompetencje kluczowe uznaje się za jednakowo ważne, ponieważ każda z nich może przyczynić się do udanego życia w społeczeństwie wiedzy, zakresy wielu spośród tych kompetencji częściowo się pokrywają i są powiązane, aspekty niezbędne w jednej dziedzinie wspierają kompetencję w innej (Zalecenie... 2006). Oznacza to, że nie ma tutaj żadnej gradacji czy hierarchii kompetencji, a przedsiębiorczość traktuje się jako kompetencję równie ważną jak kompetencje językowe, cyfrowe czy matematyczne.

Należy także zauważyć, że ten duch myślenia o przedsiębiorczości jako kompetencji jest powszechnie przyjmowany przez innych autorów, często piszących niezależnie, bez odwołania się do koncepcji kompetencji kluczowych. Przykładowo we wcześniejszych pracach T. Rachwała $(2005,2006)$ podejmujących problematykę definicji przedsiębiorczości i cech osoby przedsiębiorczej oraz w słowniku szkolnym do podstaw przedsiębiorczości (Rachwał 2004) zauważyć można podobne podejście, choć na etapie ich tworzenia koncepcja kompetencji kluczowych nie była upowszechniona (pierwsze zalecenie opublikowano pod koniec 2006 r.). Wiele elementów, w tym także takich nieoczywistych jak zdolność do empatii czy postępowanie etyczne, jest wspólnych, co świadczy o podobnym myśleniu o kompetencjach przedsiębiorczych różnych specjalistów z niezależnych od siebie ośrodków badawczych. Podobnie twórcy nowej podstawy programowej do podstaw przedsiębiorczości, pracując niezależnie od zespołu roboczego Komisji Europejskiej, jeszcze przed ogłoszeniem nowego ujęcia w formie Zalecenia Rady UE (2018), zdecydowali się na wprowadzenie elementów, które pojawiły się później w nowej europejskiej definicji. Przejawem tego jest oparcie jej na założeniu, że podstawą kształtowania kompetencji przedsiębiorczych uczniów jest rozumienie procesów gospodarczych i świata finansów, a więc wiedza ekonomiczna i finansowa. Treści te stanowią dwa pierwsze działy nowej podstawy programowej (Rachwałi in. 2018). Wyakcentowano w niej także m.in. proaktywność, innowacyjność, podejmowanie świadomych decyzji, przyjmowanie postaw etycznych i społecznej odpowiedzialności, co zostało uwypuklone w nowej deskrypcji przedsiębiorczości jako kompetencji kluczowej. Należy więc uznać, że nowa podstawa programowa, choć powstała przed ogłoszeniem nowego zalecenia w sprawie kompetencji kluczowych, jest w pełni zgodna z europejską definicją przedsiębiorczości. Można więc mówić o pełnej, przynajmniej formalnej, implementacji zalecenia (2018) w polskim sys- 
temie edukacji. Dużo jednak w procesie jego wdrażania zależy od kompetentnych nauczycieli, nie tylko podstaw przedsiębiorczości, ale także innych przedmiotów. Ich wpływ na proces kształtowania kompetencji przedsiębiorczych ucznia - obok niego samego - jest decydujący. Nawet najlepsze zapisy europejskiej definicji przedsiębiorczości czy podstawy programowej nie spełnią swojej roli, jeśli nie będzie chęci do ich poznania i implementacji w praktyce szkolnej. Wiele też zależy od przedsiębiorczości samych nauczycieli. Pozytywny sygnał w tym zakresie wynika z badań ankietowych M. Borgiasz (2017), które wykazały przekonanie nauczycieli o tym, że kształtowanie młodego człowieka może odbywać się tylko przez przyjmowanie przez nich postaw przedsiębiorczych oraz dosyć wysoką samoocenę nauczycieli wielu kompetencji własnych w zakresie przedsiębiorczości.

\section{Podsumowanie i wnioski końcowe}

Należy stwierdzić, że mimo niejednoznaczności i wieloznaczności pojęcia przedsiębiorczości i wielu różnych perspektyw badawczych i ujęć tego zjawiska, istnieje dosyć powszechna zgoda, przynajmniej w krajach europejskich, co do jej definiowania na potrzeby systemu edukacji. Pewną bazę stanowi definicja przedsiębiorczości jako kompetencji kluczowej, która choć niedoskonała, ewoluuje w dobrym kierunku, o czym świadczy jej nowa deskrypcja z 2018 r. Ponadto duch podobnego myślenia o tym, czy powinna być przedsiębiorczość na potrzeby edukacyjne, najpierw określana w Polsce jako zestaw cech osobowości i postawa człowieka, a później jako zestaw kompetencji, widoczny jest w pracach innych autorów. Do europejskiej definicji mocno nawiązali badacze realizujący projekt EntreComp, którego zadaniem było stworzenie modelu koncepcyjnego przedsiębiorczości jako kompetencji oraz zapisy polskiej podstawy programowej do podstaw przedsiębiorczości dla szkół średnich. Pozostaje więc mieć nadzieję, że Polska będzie nadal przykładem europejskiego lidera we wdrażaniu tych, w tym wypadku niezaprzeczalnie bardzo dobrych zaleceń rozwiązań w systemie edukacji. Mocna pozycja podstaw przedsiębiorczości jako obowiązkowego przedmiotu kształcenia ogólnego w szkole średniej, obecność elementów edukacji w zakresie przedsiębiorczości na niższych poziomach edukacji, już od przedszkola² daje podstawy 
do pozytywnego myślenia o efektach kształtowania kompetencji przedsiębiorczych polskich uczniów.

Należy zdawać sobie oczywiście sprawę, że część kompetencji przedsiębiorczych jak wytrwałość, proaktywność, zapał do pracy, pewność siebie czy odpowiedzialność jest trudna do wyuczenia $w$ toku edukacji szkolnej. Raczej można mówić tutaj o procesie uczenia się czy stawania się przedsiębiorczym. Dlatego konieczne jest odpowiednie podejście nauczycieli do uczniów, przede wszystkich stosowanie odpowiednich metod nauczania, z reguły innych niż tradycyjne, wykorzystywane w przypadku zajęć z innych przedmiotów. Bardziej tutaj chodzi przecież o inspirowanie uczniów do rozwijania w sobie tych kompetencji niż przekazywanie wiedzy jak być przedsiębiorczym. Ważna jest też świadomość kształtowania kompetencji przedsiębiorczych w ramach wszystkich przedmiotów szkolnych. W polskim systemie edukacji mamy jednak rzeszę dobrze wykształconych nauczycieli, którzy są w stanie sprostać temu zadaniu. Powinno to być jednak otoczone troską ze strony państwa, czego przejawem - oprócz wysokiej jakości kształcenia nowej kadry pedagogicznej - powinien być także rozwój zawodowy poprzez kursy i studia doskonalące. Wydają się one szczególnie ważne w przypadku nauczycieli przedmiotów innych niż podstawy przedsiębiorczości, aby mieli świadomość potrzeby i umiejętność rozwijania kompetencji przedsiębiorczych uczniów w ramach różnych przedmiotów, lekcji wychowawczych i innych zajęć w szkole. 


\section{Bibliografia}

$\rightarrow$ Bacigalupo, M., Kampylis, P., Punie, Y., Van den Brande, G. (2016), EntreComp: The Entrepreneurship Competence Framework. Luxembourg: Publication Office of the European Union.

$\rightarrow$ Białasiewicz, M. (2008), Przedsiębiorczość - pożądana kompetencja [w:] „Studia i Prace Wydziału Nauk Ekonomicznych i Zarządzania Uniwersytetu Szczecińskiego", nr 1, s. 7-16.

$\rightarrow$ Borgiasz, M. (2017), Kompetencje przedsiębiorcze - ich rola i znaczenie w pracy współczesnego nauczyciela [w:] „Szkoła - Zawód - Praca”, z. 14, s. 185-201.

$\rightarrow$ Borowiec, M., Rachwał, T. (2011), Kształtowanie postaw przedsiębiorczych na lekcjach geografii wyzwaniem edukacyjnym w procesach globalizacji [w:] „Przedsiębiorczość - Edukacja”, nr 7, s. 321-332.

$\rightarrow$ Brzozowski, T. (2007), "Przedsiębiorczość" - pojęcie polisemiczne czy niewłaściwie rozumiane? Próba systematyzacji [w:] „Przedsiębiorczość - Edukacja”, nr 3, s. 196-203.

$\rightarrow$ Carlebach, E. (2016), Teach us to be the authors of our own lives [w:] "Live \& Learn", nr 37, s. 7-9.

$\rightarrow$ Cieślik, J. (2014), Przedsiębiorczość, polityka, rozwój, Warszawa: Wydawnictwo Akademickie Sedno.

$\rightarrow$ Cieślik, J. (2015), Miejsce przedsiębiorczości w strukturze nauk o zarządzaniu [w:] „Kwartalnik Nauk o Przedsiębiorstwie”, nr 2, s. 59-69.

$\rightarrow$ Gaweł, A. (2013), Proces przedsiębiorczy. Tworzenie nowych przedsiębiorstw, Warszawa: Difin.

$\rightarrow$ Glinka, B., Gudkova, S. (2011), Przedsiębiorczość, Warszawa: Oficyna Wolters Kluwer business.

$\rightarrow$ Godlewska-Majkowska, H. (2011), Atrakcyjność inwestycyjna polskich regionów i przedsiębiorczość regionalna - ujęcie kompleksowe [w:] „Atrakcyjność inwestycyjna a przedsiębiorczość regionalna w Polsce", Studia i Analizy Instytutu Przedsiębiorstwa, s. 25-47. 
$\rightarrow$ Kompetencje kluczowe. Realizacja koncepcji na poziomie szkolnictwa obowiq̨zkowego, 2005, Warszawa: Eurydice, Fundacja Rozwoju Systemu Edukacji.

$\rightarrow$ Korpysa, J. (2013), Kompetencje przedsiębiorcze właścicieli MSP [w:] „Przedsiębiorczość i Zarządzanie", nr 14, z. 3, s. 169-178.

$\rightarrow$ Kraśnicka, T. (2001), Przedsiębiorczość jako przedmiot badań ekonomistów [w:] Ekonomia, nr 4, s. 187-200.

$\rightarrow$ Kwiatkowski, S.M. (2018), Kompetencje przyszłości [w:] S.M. Kwiatkowski (red.), Kompetencje przyszłości, Warszawa: Fundacja Rozwoju Systemu Edukacji, s.14$-29$.

$\rightarrow$ Mitchelmore, S., Rowley, J. (2010), Entrepreneurial competencies: a literature review and development agenda. International [w:] „Journal of Entrepreneurial Behaviour \& Research", nr 16(2), s. 92-111.

$\rightarrow$ Pilewicz, T. (2012), Region jako organizacja przedsiębiorcza w zarzq̨dzaniu strategicznym, [w:] „Kwartalnik Nauk o Przedsiębiorstwie”, nr 3, s. 27-35.

$\rightarrow$ Piróg, D. (2013), Absolwenci szkół wyższych na rynku pracy w warunkach kryzysu [w:] „Przedsiębiorczość - Edukacja”, nr 9, s. 302-316.

$\rightarrow$ Piróg, D. (2014), Uwarunkowania przedsiębiorczości absolwentów szkół wyższych: założenia teoretyczne i stan rzeczywisty [w:] „Przedsiębiorczość - Edukacja", nr 10, s. 306-315.

$\rightarrow$ Piróg, D. (2015), Kompetencje z zakresu przedsiębiorczości: rozważania teoretyczne i ich ilustracje w obszarze szkolnictwa wyższego [w:] „Przedsiębiorczość - Edukacja", nr 11, s. 364-376.

$\rightarrow$ Piróg, D. (2016), Wybrane determinanty przedsiębiorczości indywidualnej-zarys stanu badań [w:] „Przedsiębiorczość - Edukacja”, nr 12, s. 300-314.

$\rightarrow$ Płaziak, M., Rachwał, T. (2015), "Przedsiębiorczy region” - zarys koncepcji w świetle analizy roli przedsiębiorczości w krajowej strategii rozwoju regionalnego [w:] „Przedsiębiorczość - Edukacja”, nr 11, s. 37-49.

$\rightarrow$ Rachwał, T. (2004), Podstawy przedsiębiorczości - słownik dla liceum ogólnokształcącego, liceum profilowanego i technikum, Warszawa: Wydawnictwo Nowa Era.

$\rightarrow$ Rachwał, T. (2005), Kształtowanie postaw uczniów na lekcjach podstaw przedsiębiorczości [w:] „Przedsiębiorczość-Edukacja”, nr 1, s.137-144.

$\rightarrow$ Rachwał, T. (2006), Kształtowanie postaw przedsiębiorczych w edukacji szkolnej [w:] Szkoła w nauce i praktyce edukacyjnej, t.II, B. Muchacka (red.), Kraków: Oficyna Wydawnicza "Impuls", Akademia Pedagogiczna w Krakowie, s.427-434.

$\rightarrow$ Rachwał, T. (2018), Research Issues of the Function of Entrepreneurship in the Socio-Economic Development of Spatial Systems in Polish Economic Geography [w:] „Prace Komisji Geografii Przemysłu Polskiego Towarzystwa Geo- 
graficznego" ["Studies of the Industrial Geography Commission of the Polish Geographical Society"], nr 32(4), s. 149-162.

$\rightarrow$ Rachwał, T., Kilar, W., Kawecki, Z., Wróbel, P. (2018), Edukacja w zakresie przedsiębiorczości w wychowaniu przedszkolnym, szkole podstawowej i szkołach średnich w świetle nowej podstawy programowej [w: „Przedsiębiorczość - Edukacja", nr 14, s. 389-424.

$\rightarrow$ Rachwał, T., Kurek, S., Boguś, M. (2016), Entrepreneurship Education at Secondary Level in Transition Economies: A Case of Poland [w:] "Entrepreneurial Business and Economics Review", nr 4(1), s. 61-81.

$\rightarrow$ Słownik języka polskiego, 2005, Warszawa: Wydawnictwo PWN.

$\rightarrow$ Szkurłat, E., Hibszer, A., Piotrowska, I., Rachwał, T. (2018) Podstawa programowa geografii źródłem nauczycielskich wyzwań [w:] A. Hibszer, E. Szkurłat (red.), Nauczyciel geografii wobec wyzwań reformowanej szkoły, Seria: Prace Komisji Edukacji Geograficznej Polskiego Towarzystwa Geograficznego, t. 8, Sosnowiec: Komisja Edukacji Geograficznej PTG, s. 13-31.

$\rightarrow$ Szromnik, A. (2012), Miasto przedsiębiorcze i innowacyjne w regionie [w:] „Zeszyty Naukowe Uniwersytetu Szczecińskiego. Ekonomiczne Problemy Usług", $\mathrm{nr}$ 98, Przedsiębiorczość szansą rozwoju regionu. T. 2, Kształtowanie przedsiębiorczości, s. 323-346.

$\rightarrow$ Tracz, M. (2006), Rola i znaczenie „podstaw przedsiębiorczości” w kształceniu ogólnym [w:] „Przedsiębiorczość - Edukacja”, nr 2, s. 222-225.

$\rightarrow$ Wach, K. (2015), Przedsiębiorczość jako czynnik rozwoju społeczno-gospodarczego: przegląd literatury [w:] „Przedsiębiorczość-Edukacja” , nr 11, s. 24-36.

$\rightarrow$ Wach, K. (2014a), Edytorial: Przedsiębiorczy uniwersytet [w:] „Horyzonty Wychowania", nr 13(28), s. 3-6.

$\rightarrow$ Wach, K. (2014b), Paradygmat gospodarki przedsiębiorczej a polityka wspierania przedsiębiorczości (rozdział 1) [w:] K. Zieliński (red.), Formy i przejawy współczesnej przedsiębiorczości w Polsce, Warszawa: Difin, s. 13-30.

$\rightarrow$ Wach, K. (2014c), Edukacja dla przedsiębiorczości: pomiędzy przedsiębiorczq pedagogikq̨ a edukacjq̨ ekonomicznq i biznesowq [w:] „Horyzonty Wychowania”, nr 13(28), s. 11-31.

$\rightarrow$ Zalecenie Parlamentu Europejskiego i Rady z dnia 18 grudnia 2006 r. w sprawie kompetencji kluczowych w procesie uczenia się przez całe życie (2006/962/WE).

$\rightarrow$ Zalecenie Rady z dnia 22 maja 2018 r. w sprawie kompetencji kluczowych w procesie uczenia się przez całe życie (Tekst mający znaczenie dla EOG), Dz. UE 2018/C 189/01.

$\rightarrow$ Zioło, Z. (2016). Zarys uwarunkowań kształtowania przedsiębiorczego uniwersytetu [w:] „Horyzonty Wychowania”, nr 15(35), s. 29-54. 
$\rightarrow$ Zioło, Z. (2012), Miejsce przedsiębiorczości w edukacji [w:] „Przedsiębiorczość - Edukacja", nr 8, s. 10-23.

$\rightarrow$ Zioło, Z., Rachwał, T. (2012), Entrepreneurship in geographical research [w:] P. Churski (red.), "Contemporary Issues in Polish Geography", Poznań: Bogucki Wydawnictwo Naukowe, s. 135-155. 